\title{
A NARRATION OF A PHYSICAL SCIENCE TEACHER'S EXPERIENCE OF IMPLEMENTING A NEW CURRICULUM
}

\section{Oscar Koopman}

Cape Peninsula University of Technology

Email: koopmano@cput.ac.za

\section{Lesley Le Grange}

Stellenbosch University

\section{Karen Joy de Mink}

University of the Western Cape

\section{ABSTRACT}

This article narrates the lived experiences of a Physical Science teacher named Thobani (pseudonym) in implementing a new curriculum in South Africa. Drawing on the work of Husserl and Heidegger, the article describes the objects of direct experience in Thobani's consciousness about his life as a learner and teacher as revealed during an in-depth semi-structured interview conducted from two perspectives. The genealogical part of the interview chronicled how his knowledge of Physical Science had unfolded in his life as a learner and subsequently as a teacher; the portraiture perspective recounted the often traumatic events of his personal life and the circumstances that had informed his decision to become a teacher. Theoretically, the findings reveal how an incompetent Physical Science teacher had hampered his understanding of the fundamentals of the subject, and how the lack of support from the Department of Education and his head of department had retarded the implementation process. The insights gleaned from this phenomenological investigation into

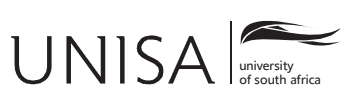

Education as Change www.educationaschange.co.za Volume 20 | Number 1 | 2016 pp. $149-171$

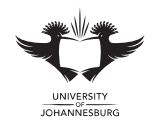

DOI: http://dx.doi.org/10.17159/1947-9417/2016/560 Print ISSN 1682-3206 | Online 1947-9417

(c) 2016 The Authors 
the thought processes of a teacher introduced to a new curriculum could have potentially transformative effects for policy-makers, curriculum planners and teacher educators at a time when South African teachers are yet again faced with the implementation of a new curriculum.

Keywords: genealogical perspective, portraiture perspective, phenomenological interview, implementation process, transformative effects, implementation of a new curriculum

\section{INTRODUCTION}

The phenomenological investigation recounted in this paper, which forms part of a broader study, focuses on the lived experiences of a black Physical Science teacher who teaches in a so-called informal settlement in the Western Cape Province of South Africa. For the most part, people in informal settlements live in selfconstructed makeshift shelters known as shacks. These dwellings are built in such close proximity to one another that they form severely congested settlements often associated with serious health and social problems. The establishment of informal settlements was the result of the racist 1913 Land Act, which relegated black South Africans to so-called 'native reserves'; the notorious Group Areas Act of 1966, which forced South Africans to live in designated areas based on racial classification; and rapid urbanisation as large numbers of people migrated to the cities in search of better economic opportunities. The learners whom Thobani teaches Physical Science live in such an informal settlement township community (see Figure 1).

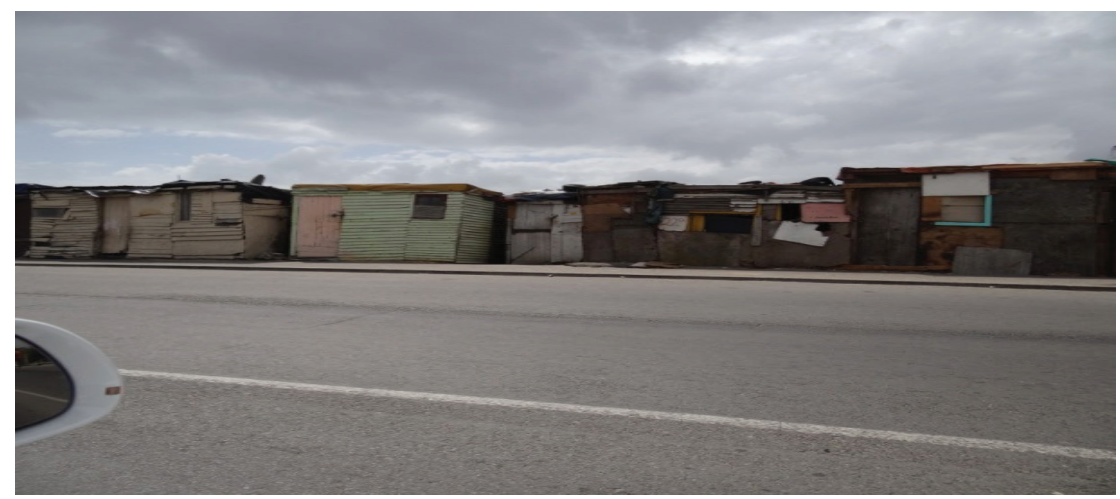

Figure 1: The community in which Thobani teaches

In South Africa, a large number of studies focus on the implementation of a new science curriculum (see, for example, Jansen 1999; Rogan \& Grayson 2003; and Aldous 2004). Rogan and Grayson (2003) have attempted to develop a theoretical 
model for curriculum implementation in developing countries based on the following aspects to minimise the waste of resources and demoralising experiences of teachers: a profile of implementation, the capacity to innovate, and support structures. Rogan (2004) examined the challenges that a new science curriculum might pose for science teachers, how well they cope with the implementation process, and concluded that, without continuous support and professional development, the process is most likely to fail. In a similar study, Kriek and Basson (2008) found that, although teachers were positive about the new curriculum, they had concerns about the lack of resources and their ability to teach the curriculum content. This is congruent with the views of Brodie, Lelliot and Davis (2002) who argue that teacher qualifications, specialised subject knowledge, access to resources and support structures in schools are determining factors in how teachers respond to a new curriculum. Aldous's (2004) study looked at the factors that influence teachers' perceptions but it does not delve deep enough into the mind-sets of teachers to explain their thinking or the rationalisation undergirding their perceptions when confronted with curriculum change.

These studies are of great value because they provide answers to specific questions of curriculum implementation. Researching teachers' lived experiences of the implementation of a new curriculum could add to this growing body of work and provide answers to the question why teachers do what they do. In the last two decades, both internationally and in South Africa, there has been a significant upsurge in researching the lived experiences of science teachers phenomenologically (for example, see Hammer 1995; Domert, Airy, Linder \& Kung 2007; Clarke and Linder 2006; Koopman 2013). For example, Clarke and Linder's (2006) study reports on the lived experiences of a black female teacher who teaches in an informal settlement in a large, overcrowded and under-resourced school, and her struggle to implement the outcomes-based curriculum. Although these studies reflect a broad phenomenological approach, they do not follow through with a detailed phenomenological analysis of the data. Therefore, the research on which this article is based aimed to use not only a phenomenological data-collection process, but Husserlian phenomenology to represent the findings from a genealogical angle, and Heideggerian phenomenology to represent them from a portraiture angle. The next section of the article discusses the curriculum that Thobani had to implement.

\section{THE SHIFT TO THE FURTHER EDUCATION AND TRAINING (FET) NATIONAL CURRICULUM STATEMENT (NCS)}

In March 1997, under the rubric of Curriculum 2005 (C2005), indicating the final year of implementation in all school grades, the South African Department of Education (DoE 1997) launched its first post-apartheid curriculum. It was envisaged that this 
new curriculum would replace content-based education (CBE) with outcomes-based education (OBE), and teacher-centred pedagogies with learner-centred pedagogies. Furthermore, OBE was intended to redress the legacy of apartheid by promoting the development of skills throughout the school-leaving population so as to prepare South Africa's workforce for participation in an increasingly competitive global economy.

Since the gradual phasing in of the new curriculum, it has undergone extensive revision, following a period of vociferous debate and fierce contestation as to the merits of OBE (see, for example, Jansen \& Christie 1999). There were also other concerns such as the difficulties of implementing the new curriculum in resourcepoor contexts. For example, Chisholm,Volmink, Ndhlovu et al. (2000), the authors of the Report of the Review Committee on Curriculum 2005, observed that historically disadvantaged schools lacked the essential resources - reference and textbooks, stationery, photocopying facilities and other technologies of teaching - needed to implement Curriculum 2005 effectively. This finding is corroborated by empirical studies conducted by Jansen (1999) and Le Grange and Reddy (2000). Based on its members' visits to schools, the review committee made several recommendations in its review of published literature on Curriculum 2005, its review of submissions made by organisations and individuals, and of further investigations. The outcome of the review process was the development of a Revised National Curriculum Statement (RNCS) for General Education and Training (GET) (DoE 2002). The RNCS was implemented in schools in the year 2002, and in 2006 a new National Curriculum Statement for Further Education and Training (DoE 2006) was phased in. General Education and Training begins with a reception year and ends with Grade 9, and Further Education and Training focuses on Grades 10 to 12.

One of the major changes that took place with the introduction of the NCS for Physical Science was a shift in the subject content prescribed. For the first time, topics such as two-dimensional motion and two-dimensional momentum were included in the Mechanics section. Furthermore, other new materials in the Physics section included lasers, the Doppler Effect, two-dimensional and three-dimensional waves, electrodynamics, electronics, the mechanical properties of light, and electromagnetic radiation. In the Chemistry section, there were few changes to the previous curriculum, but the topics were more detailed and extensively elaborated upon. The NCS aims to produce a learner who can think logically, analytically, holistically, and factually (DoE 2006, 2008). Furthermore, teachers are expected to be designers of learning programmes and materials, researchers and subject specialists (see DoE 2003).

At the time of the research reported on in this article, the NCS was the only legal curriculum document for teachers. Thobani and all the other Physical Science teachers were expected to fulfil the requirements of the NCS. In the NCS policy for Physical Science, each learning outcome (LO) was accompanied by assessment standards (ASs), which describe the ways in which learners should attain these 
outcomes. According to the NCS policy document (DoE 2003), ASs are vehicles of knowledge, skills and values through which the learning outcomes are addressed. Table 1 below represents the three LOs and selected ASs to shed light on how Physical Science was structured in the NCS curriculum. This table will be used as frame of reference to describe Thobani's understanding and interpretation of the NCS in the findings and discussion section.

Table 1: Assessment standards for Physical Science for the respective learning outcomes in the FET phase

\begin{tabular}{|l|l|l|l|}
\hline & $\begin{array}{l}\text { Learning Outcome 1: } \\
\text { Scientific inquiry and } \\
\text { problem-solving (LO 1) }\end{array}$ & $\begin{array}{l}\text { Learning Outcome } \\
\text { 2: Construction of } \\
\text { scientific knowledge } \\
\text { LO 2) }\end{array}$ & $\begin{array}{l}\text { Learning Outcome 3: } \\
\text { The nature of science } \\
\text { and its relationship to } \\
\text { technology, society and } \\
\text { the environment (LO 3) }\end{array}$ \\
\hline $\begin{array}{l}\text { Assessment } \\
\text { standards } \\
\text { (AS) }\end{array}$ & $\begin{array}{l}\text { Planning and } \\
\text { conducting an } \\
\text { investigation }\end{array}$ & $\begin{array}{l}\text { Recalling and stating } \\
\text { concepts }\end{array}$ & $\begin{array}{l}\text { Integrating science } \\
\text { with technology and } \\
\text { Mathematics }\end{array}$ \\
\cline { 2 - 4 } & $\begin{array}{l}\text { Accurate and reliable } \\
\text { collection of data }\end{array}$ & $\begin{array}{l}\text { Explaining } \\
\text { interrelationships } \\
\text { between facts and } \\
\text { concepts }\end{array}$ & $\begin{array}{l}\text { Impact of science } \\
\text { on ethical and moral } \\
\text { arguments }\end{array}$ \\
\cline { 2 - 4 } & $\begin{array}{l}\text { Interpreting data and } \\
\text { seeking patterns and } \\
\text { trends }\end{array}$ & $\begin{array}{l}\text { Applying scientific } \\
\text { knowledge }\end{array}$ & $\begin{array}{l}\text { Impact of science on } \\
\text { the environment and } \\
\text { social development }\end{array}$ \\
\hline
\end{tabular}

(Constructed from DoE Policy Document, 2003)

The LOs for Grades 10 to 12 are the same but the ASs differ across grades, serving to indicate the level at which the LOs must be achieved in each grade. For example, in Grades 10 to 11 (for LO1), a learner is expected to conduct a scientific investigation and collect data for interpretation. In Grade 12, the learner must design and conduct an experiment to collect data from which to draw inferences, and interpret the data to verify or falsify a particular hypothesis. The attainment of these skills (LO1) is evident when a learner uses scientific reasoning to explain the verification or falsification of his or her hypothesis. Learning outcome 2 focuses on the construction of scientific knowledge, whereas a Grade 10 learner is only expected to state the basic prescribed scientific knowledge (DoE 2003). In Grades 11 to 12, learners must define and discuss the basic prescribed scientific knowledge. Each of the concepts 
builds upon the previous one, from one grade to the next, which is consistent with the goal of conceptual progression. Bennet (2002:83) points out that conceptual progression is desirable in a curriculum 'as it represents elements of curriculum implementation and delivery that are crucial in synchronising policy, teaching, assessment and learning'. Thus, as learners progress through the FET phase, their knowledge of scientific concepts is strengthened. The role of the NCS teacher is illustrated by way of an example below.

When teaching Boyle's Law, the teacher must not merely guide the learners to collect data to verify textbook information as in the former apartheid curriculum. Instead, the teacher now has to develop the learners' insight into the objectives and rationale behind these experiments by guiding them to understand what led Boyle to arrive at these laws. It follows that the teacher needs to be familiar with the work of Torricelli, his experimental evidence for atmospheric pressure, and his design of the barometer from which Boyle derived his theories. Furthermore, it is expected of Thobani and his colleagues to encourage their learners to develop practical skills in the Science classroom by allowing them to design their own experiments and collect similar data that will confirm the inverse proportionality relationship between volume and pressure if the temperature remains constant. The learners are then expected to link Boyle's law to real life applications such as in the tyre industry where tyres with stronger casings reduce roads accidents. In addition, the teacher must promote higher order cognitive skills in the learners in order for them to understand that an increase in temperature results in an increase in pressure; therefore, a stronger tyre casing would reduce the number of road accidents caused by tyre bursts.

The NCS in the FET band is based on three LOs: skill, knowledge, and application. Each outcome has three assessment standards, except for LO 1, which has four (for full details on the NCS for Physical Science, see Nakedi, Taylor, Mundalamo, Rollnick \& Mokeletche 2012). The goals of the NCS not only require teachers to use innovative teaching strategies but also to expand their knowledge and perceptions about how they think learners learn. Next, the epistemic and ontological nature of the study will be discussed in order to shed light on Thobani's lived world.

\section{PHENOMENOLOGISTS AS WORKERS OF EXPERIENCE}

According to Husserl (1975:5), cognition begins and ends with experience. Gadamer (1975:34) argues that experience has a condensing and intensifying meaning. He maintains that the totality of experience is found in the significant whole. This significant whole refers not only to a person's presence but to his or her complete presence. Husserl (1975:xiv) notes that this whole or unity of an object is something that is given among various appearances and not something separate and alongside it. It is considered a structural nexus that is contextually connected to reflect upon so as to give it a significant quality of meaning. Therefore, according to Husserl, 
phenomenology is a form of inquiry that describes the lived experiences of others and informs us about the participant's perception of a physical object. These perceptions provide phenomenological researchers with the necessary intellectual tools to understand human behaviour and actions and to do something about the latter when necessary.

It is widely acknowledged in the philosophical literature that lived experience is best captured using a phenomenological framework. The phenomenological school is divided into two groups whose philosophical orientations derive from the work of the German philosophers Husserl (1859-1938) and Heidegger (1889-1976), respectively. Both groups of scholars concentrate their research activities on the idea of lived experience. Although both groups are located within the phenomenological tradition of researching lived experience, there are marked differences between them. Husserl's (1975) pursuit of truth about human existence focuses on the theoretical and philosophical aspects of people's experience, with the emphasis on bracketing and essences. Husserl (1975) tirelessly pointed out that, in essence, phenomenology is a pure science of consciousness, or a science of pure phenomena that are absolute and unique. By contrast, Heidegger (1967) focuses more on the ontological dimension and contextualisation of experience. The difference between the approaches of the mentioned scholars will become evident later in the article when, in Husserlian terms, the experiences of Thobani are narrated through use of his own words without any interpretation and then followed by a Heideggerian approach whereby Thobani's experiences are interpreted by the authors based on contextual factors. Both traditions use lived experience to elucidate and validate the manner in which people experience particular phenomena through observation and interaction, which leads them to indubitable meanings of truth about individuals. Both these traditions informed this study.

Husserl (1975) argues that lived experience ('Erlebnis') is to be understood as first-person data, also referred to as eidetic data (representing the ideas of the individual). This means that first-person data are prior to any reflection given experientially to someone. Husserl (1975:xix) explains the first-person data as follows: 'We must not make assertions about that which we do not see ourselves.' He points out that such first-person data are synonymous with the meaning of the German word, 'Sachen', which in context does not refer to physical objects but to subconsciously held ideas. These subconsciously held ideas have their roots in experience, which, in our lives, refers to those matters that we value most. According to Husserl (1975:xix), the only way to access these subconsciously held ideas or structures of knowledge is through a consciousness unburdened by preconceived ideas or notions derived from the individual's personal experience or perceptions. According to Koesterbam (in Husserl 1975:xxii), this approach generates pure presentations or uninterrupted sense data derived from experience. Husserl firmly believes that an individual's consciousness is reflected in his or her presence in 
the world, which represents his or her intentionality - that is, the directedness of his or her consciousness towards the object of thought. Based on this premise, the implementation of the NCS becomes, not a description of how the teacher attempts to implement the curriculum, but how the process of implementation unfolds in his or her consciousness. Brown (1992:49) sums up the latter when he writes:

We want to understand man (sic) from his world, that is, from the meaningful ground structure of that totality of situations, events, cultural values, to which he orients himself, about which he has consciousness, and to which his actions, thoughts and feelings are related.

The above quotation expresses the main aim of the research reported to in this article, which was to delve into Thobani's consciousness to gather as much rich descriptive data as possible to capture his thoughts. In the next section, the attention shifts to the methodological orientations of the study.

\section{THE RESEARCH APPROACH}

This research on which this article is based was situated within a phenomenological methodological framework. Such a framework is specific because it illuminates the research subject's contextualised experiences - in this instance, the mental and emotional turbulence he experienced in response to the challenge of introducing a new Physical Science syllabus and to bring about renewal within his constrained teaching environment in an impoverished community. This study goes beyond the physical experiences of external events and aims to focus on the inner landscape of why he embraces or resists elements of curriculum change.

The essential interest is in exploring the objects of experience in Thobani's consciousness in order to gain deeper insight into the life world of a Physical Science teacher as revealed through his personal accounts. Husserl (1970) stresses the importance of discovering truth by understanding the human lived experience and exploring it systematically through rigorous inquiry or research. Van Manen (1984:38) writes:

As we research the possible meaning structures of our lived experiences, we come to a fuller grasp of what it means to be in the world as a man, a woman, a child, taking into account the socio-cultural and the historical traditions which have given meaning to our ways of being in the world.

In phenomenology, interviews and field notes are regarded as trustworthy and reliable forms of data construction. Given the heavy workloads and administrative responsibilities of teachers, a semi-structured, in-depth one-on-one interview - rather than an alternative form of data construction such as a descriptive essay - was used. 


\section{The interview}

The interview questions were aligned with the main aim of the research study, which was to delve into Thobani's consciousness to gather as much rich descriptive data as possible about his thoughts and feelings concerning the implementation of the NCS, and were all framed around his experiences in this regard. The in-depth interview focused attention on issues such as his feelings, beliefs, and perceptions as regards the challenges associated with the NCS. The interview commenced with knowledge questions about his experiences as a learner, specifically with reference to the school he had attended and the Physical Science teacher he had had as a learner in Grade 12. This was followed with questions about how he had experienced the introduction of the NCS, the training he had received prior to the implementation, how he felt, and what he thought about the NCS. Husserl's (1975:xix) principles of the phenomenological epoché $e^{1}$ and his dictum about the things themselves ${ }^{2}$ were adhered to during the data-gathering process as explained in the following paragraph.

During the interview, the researchers paid close attention to the verbal and nonverbal behaviour of the research subject by drawing on the resources of speech act theory, discourse analysis and communication science. Here the focus was on the length of the pauses during and between questions, the interviewee's posture and gestures during the interview, and word choices. During this phase of the recorded interview, notes were made as comprehensively as possible without any bias or judgemental evaluation. The notes that were made included the non-verbal cues, silences, word choices, and the repetition of certain words during the responses. The researchers also compiled a list of significant words used by the interviewee. For example, high frequency responses such 'yo' and 'phew' and so forth were given attention to as the interviewee tried to give emotional expression in some instances. These notes were carefully taken so that the researchers could correlate them with specific questions and responses constructed from the data (Miles and Huberman 1984).

\section{DATA EXPLICITATION}

Data explicitation is divided into two sections, namely findings and discussion. Under findings, we provide a descriptive narrative using mostly Thobani's direct words, comments and expressions as is customary in a phenomenological study. In the discussion section, we present an interpretive narrative in order to give meaning to or elucidate his direct words and to separate the essential aspects from

1 Epoche refers to the role of the researcher allowing the data to flow freely from the research participant while bracketing out his or her (researcher) own personal beliefs, feelings, perceptions and views so as not to contaminate the data.

2 The things themselves are the result of unveiling the subjective knowing or representations of the respondent as divulged in the course of the interview. 
the peripheral. Thobani's transcript was analysed by grouping together related items and responses in an attempt to arrive at an understanding of the language he used as based on his choice of words. At this stage, the researchers tried, as Husserl (1975) suggests, placing themselves in Thobani's position in an attempt to understand what he meant and intended to say during the interview. His responses were transformed into 'psychological language ${ }^{3}$, that is, interpreted and rendered psychologically, with an emphasis on how he experienced the NCS in his consciousness. We found these transformations necessary because such psychological renderings provide a deeper insight into his responses to the events that took place in his life as a child and later as a teacher.

\section{FINDINGS}

During the data explicitation process we had to enter a totally pre-suppositionless space by suspending all possible interpretations and meaning. It required from us to read the transcript with openness and we had to enter Thobani's world in order to extract meaning from what he was saying. It must be stated that at times this was difficult because each individual (e.g. Thobani) has his/her own unique way of experiencing temporality, spatiality and materiality in this world (Hycner 1985:29). Furthermore, to understand others in relation to their own inner world is even more complex, but we connected our own experiences as ex-learners and ex-teachers of Physical Science to give meaning to Thobani's lived world. In presenting the findings, we have grouped the items reflecting similar responses together and identified the following themes:

- Thobani's views on the shift from C2005 to the NCS;

- Thobani's classroom experience and understanding (interpretation) of the NCS;

- Thobani's responses to the training offered by the WCED in preparation for the implementation of the NCS.

Before we present the findings of Thobani's responses to the above themes, we wish to provide a short biography of his life as a child and learner of Physical Science. His biography was compiled by meticulously scrutinising each word, phrase, sentence and paragraph in the interview transcripts in order to distil the essence of his childhood experiences. The first part of the interview allowed us entry into his consciousness of how he experienced the world as a child in the Physical Science classroom and how he ended up in the teaching profession. These experiences provided tangible structures to reconstruct his history and subsequently his biography.

3 The dynamics of how a person's historical, social and political experiences are expressed in his consciousness. 


\section{Genealogical angle: Thobani's biography}

At the time of the interview, Thobani was 38 years old, had been teaching Physical Science at school for 13 years, held a three-year Technikon (now called University of Technology) teaching diploma, and was attempting to complete his fourth year to upgrade his qualification to a bachelor's degree. He was born and raised in an informal settlement in the Western Cape Province. Thobani describes the school he attended as a learner as a bare concrete building on a piece of open land, which he characterised as 'a resource-poor environment'. In addition, he characterises his experience of the subject Physical Science at school as a horrible and challenging ordeal. He states: 'We never understood our teacher .... I think we taught ourselves the Grade 12 syllabus.' He sardonically remarks that, as far as the subject content was concerned, the situation in the Physical Science classroom would have been better if the teacher had always been absent from class as even the practical work was non-existent.

Thobani believes that his teacher had neither any passion for the subject nor any interest in the learners. In consequence, the learners' self-esteem plummeted and they lacked confidence in responding to questions. He laments: 'We only skimmed the surface of what had to be learned for the exam, all on our own. When I chose the subject in Grade 10, I had high hopes of becoming an engineer.' However, this hope slowly faded as the result of having to cope with Physical Science as 'taught' by a teacher whom he describes as 'horrible' and 'knowing less' than the learners. In an attempt to seek help, Thobani and his fellow learners went to the principal's office to ask for a substitute, but without success. In response to a question whether the teacher was qualified to teach Physical Science, Thobani states: 'I don't know - we went to the office to find out if we can't get a substitute, but we never got a positive response. I can't even remember this teacher's name.'

In consequence of his unfavourable experience with Physical Science at school and poor matriculation results in the subject, Thobani could not gain entry to a university engineering programme. He blames his Grade 12 teacher for his misfortune, which left him with no other choice but to opt for a teaching career instead. After entering the teaching profession, Thobani hoped to make a difference to the way Physical Science was being taught in schools and set himself the goal of achieving a $100 \%$ pass rate. The following section presents a transcript of Thobani's responses in relation to the specific themes deduced from the interview transcript as a whole.

\section{Portraiture angle: Thobani's views on the shift from C2005 to the NCS}

In this section, Thobani describes how he experienced the shift from C2005 to the NCS. He explains what it was like in the early days of the implementation process 
and describes his struggle to overcome the many hindrances to his implementation of the NCS. Thobani explains:

I entered the teaching profession as a Physical Science teacher in 1998. I started during a time when there was a lot of confusion. When I started teaching, it was the introduction of OBE. Many of us were confused but I was in a better position because I was fresh coming out of school [university].

When asked about the confusing period and why he thought he was in a better position, he replied:

Most of the teachers, they did not know what to do, how to teach and the content - phew! They struggled [smiling]. I think they did not have better training but I learned a lot about the new curriculum at school [university]. I was better prepared than they because at least this new curriculum I was ready for it.

Thobani further describes how he struggled with his older colleagues who found it difficult to accept the new policy changes prescribed by the NCS, and how their negative mind-set regarding the NCS affected him. He said:

You see, the people like my HOD [Head of Department], he's coming from the old way of teaching. The traditional, the old way, which was in the apartheid era. So we were always at loggerheads as to how much we must teach and how much mustn't we teach the learners.

When asked how he felt about the new curriculum changes (referring to the shift from $\mathrm{C} 2005$ to the NCS), he explained:

I was very happy because my learners they benefited. They were now better prepared for university. I did not do this new content [when he was a learner] that was now added to the curriculum but they did it, so that made me very happy. I use it to help them, my students. I always tell them it is a good thing this new shift to NCS.

At this point in the interview it was evident that Thobani favoured the new curriculum but that he was troubled by the opposition from his HOD and older colleagues. As he was searching through his memory and reflecting on his past experiences, he appeared to be reliving the accumulated effects of his experiences as a learner and the objections that he faced from his teaching colleagues many years later. The researcher (first author) noticed the seriousness and anger with which he spoke about how he felt at the time. The inner turmoil that he was experiencing was also evident from his facial expressions and gestures. While he was reflecting and speaking, his arms were tightly folded across his stomach as if in an attempt to contain himself and not show too much emotion. His non-verbal gestures, the long pauses between responses, and his choice of words appeared to be an attempt to find the appropriate words to describe his emotions. It represented a symbolic sense of his need to protect himself as well as an attempt on his part to express his agitation politely in the company of his older interlocutors. It can be assumed that he was well aware of the 
fact that his interlocutors did not support the curriculum change. Haney, Czerniak and Lumpe (1996) note that when more experienced teachers are favourably disposed towards a curriculum change, it also inspires novice teachers to respond positively to the proposed policy changes in education.

\section{Thobani's classroom experience and interpretation of the NCS}

Asked how he felt about the new NCS curriculum and whether he had implemented it in his classroom, Thobani had the following to say:

Phew! One has no choice but to apply the NCS because, you see, OBE goes along with lots of things. There are many things that one needs to assess - even the seating of the learners. You can't allow learners to be sitting alone or on their own. Now, teaching OBE, one has to teach with context in mind. I am there - I am comfortable with teaching with a context. I have always done that.

The image Thobani portrays about the NCS in the above quotation suggests that it requires new ideas and more effort for the assessment of tests and assignments, classroom management (seating arrangements), the application of knowledge (context), and preparation. His statements 'one has no choice' and 'there are many things one has to assess' subconsciously reflect the magnitude of the task of implementing the NCS. When he was asked how often he did practical work (see Table1.1: LO 1: Practical investigation and problem-solving), he pointed out that time did not allow him to do as much practical work as he would have liked to do. He also complained about the lack of resources that hindered his ability to do practical work. He commented: 'I do at least one practical per term (every 4 months) because there is no equipment.' It should be borne in mind that the NCS requires teachers to use LO 1 of which ASs 1.1, 1.3 should form the basis of the lessons they teach. When asked whether he understood the curriculum and what was demanded of him to be an effective implementer, he said:

After 13 years of teaching, I must by now know and understand the curriculum. No, those concepts we have grasp them. They were a problem when the new syllabus was being introduced ... we had to implement them but now after about 13 years of teaching I think I understand them.

When asked about how much time in his lessons he devoted to LO 3, specifically ASs 3.1 and 3.2, he pointed out that his focus was on teaching the content (LO 2). He said: 'I hardly have time to complete the content [LO 2: AS 2.1: Recalling and stating concepts], so I do that [LO 3] when I have time.' On the subject of assessment, he asserted that he assessed his learners regularly through activities such as workbook exercises, asking questions, tests, examinations, and allowing the learners to work in groups (LO 2: ASs 2.1 and 2.2). He explained: 'All those tools I'm using them but, when it comes to assessment. I assess every day.' He reiterated that he did not 
experience any problems teaching the content. When asked if he understood the content, he replied:

It takes a lot of my own time at home. I spent a lot of time on my own studying to understand the curriculum. Even the topics I made sure I understand. You know, what helped me would be the exemplars that were provided by the WCED [Western Cape Education Department]. I was never taught those topics at school, not even at university. I was never taught but most of the things that I am teaching currently I had to read them on my own to understand them.

The following citation describes what Thobani considered to be the most challenging part of implementing the NCS:

My biggest challenge was, first of all, I did not know how to prepare my lessons with the different outcomes in mind. During that time, I only went to class not knowing while teaching whether I was meeting the demand of those critical and developmental outcomes but, after some time, I learned what was expected of me and did so.

When asked who had helped him to understand these outcomes, he stated that most of the work he had to learn on his own and added: 'I am a lifelong learner and am slowly becoming a specialist.'

\section{Portraiture angle: Thobani's views on the training offered by the Department of Education prior to the implementation of the NCS}

The following quotation describes Thobani's view on the training he received:

This training it was too short. Yo, yo, yo! I expected much more from these training sessions. It was a big joke and a real waste of my time. They could not fit into these sessions all the materials one needed to know ... yo! ${ }^{4}$

When asked whether or not the training was helpful, he had the following to say:

I would say, if I can rate them [the workshops], they would be $20 \%$ helpful. The other $80 \%$ was more confusing. You know why I am saying so: it's because the WCED they took some of us [teachers] and made us curriculum advisors. Those curriculum advisors were the ones that were also confused. Those guys they were given the opportunity to come back to us. One could sense they were not confident - they did not know what they were saying in those workshops.

When asked how he felt about and who had arranged the workshops, and how and when it had been done, he replied:

I still remember, we'll stay after school when one is tired. We'll stay for two to four hours or on Saturdays two to four hours. That is the maximum time we spent on those workshops.

4 'Yo' is an expression of amazement in the black community in South Africa. 
Some of the workshops were also offered during the June holidays for a period of one week by the curriculum advisors.

Thobani felt that the training he had received raised more questions than it answered, which is why he constantly referred to the training sessions or workshops as confusing. He had hoped that the training offered by the WCED would allay all his fears, anxieties and insecurities and would adequately prepare him for the effective implementation of the NCS. Instead he was left disappointed as he had to learn most of what he needed to know on his own. He pointed out in an earlier excerpt that the workshops were too short to fit in all the materials to be learned, and in the above quotation he highlights the fact that the training was offered during school holidays, weekends, and after school when he needed to rest.

\section{DISCUSSION}

\section{The 'horrible Physical Science teacher'}

To understand Thobani's descriptive experiences more clearly, we firstly availed ourselves of the resources of Heideggerian phenomenology to write an interpretive narrative based on his responses. Heideggerian phenomenology allowed the researchers to give meaning to Thobani's experiences by providing an interpretive narrative based on the researcher's interaction with the interviewee. It allowed the researchers to connect the context within which the interviewee was teaching, the mood that existed during the interview, as well as the researchers' expert opinion on how they thought the interviewee experienced the phenomena. In this research project, it allowed the researchers to construct Thobani's phenomenological attitude towards Physical Science, which started at school when he was a learner. Secondly, we strove to present his views regarding the shift from C2005 to the NCS. Thirdly, the approach allowed us to discuss the perception of the influence and role his HOD and older colleagues played in the implementation, and, in conclusion, the poor training provided by the department of education.

Firstly, constructing an interpretive narrative from Thobani's biography was a complex task. The interview as a whole provided meaning and insight into specific events and how these events directed the course of his life. From this we could separate minor issues from major ones and deduce how the major events impacted on his being and becoming. Our personal experiences both as learners and teachers of Physical Science (first and second author) and the major events that happened in Thobani's life allowed us entry into his consciousness to construct his biography. Furthermore, our use of Heideggerian phenomenology in this section was intended to assist us in achieving a deeper insight into the objects of experience in his consciousness and did not in any way imply an intention on our part to critique his descriptions and other responses. Rather, it was our objective to reveal how the 
complex workings of his conscious as well as his subconscious mind influenced his understanding of Physical Science as a school subject.

What stands out in Thobani's biography was the negative influence that his teacher had on him as a learner and the environment in which he received his teaching. Throughout the interview he continually pointed out what a 'horrible Physical Science teacher' he had had. This experience had created the subconscious perception that Physical Science was a difficult subject. This is evident from his statement, 'we did not understand our teacher and went to the principal's office to ask for a substitute', and from the fact that he lamented the poor examination results that prevented him from studying the subject of his dreams: engineering.

Many studies have shown that poor teaching leads to a poor understanding of science (for example, see MacDonald \& Rogan 1988; Ogunniyi 1996). Olitsky (2006:209) argues that this problem is not confined to a lack of resources, but is directly related to a teacher's inability to guide and nurture a learner to become a member of the scientific community. Olitsky (2006:209) further argues that the learning of science is more than just a cognitive activity in that entails the development of a social identity associated with scientific practice and discourse that should start at school level. To acquire this kind of knowledge base in science, the learner needs to develop a sense of somehow belonging to the world of science, which could emerge from a strong relationship with his or her teacher.

In Thobani's case, the lack of both a role model and a positive exposure to the teaching of Physical Science fostered a deep-seated resentment towards the teaching of the subject he loved and a psychologically ambivalent attitude towards science. The fact that Thobani's school teacher followed the doctrine of fundamental pedagogics, Clark and Linder (2006) argue, could have major implications for the way he (Thobani) views the subject. In his subconscious mind, science had become associated with an objective, distant and meaningless subject aggravated by his teacher's incompetence and narrow ways of looking at the world. Thobani's story begs the question to what extent his understanding of science would have been different if he had had a competent and passionate teacher with a sound understanding of science, and what effect that would have had on his understanding of Physical Science. Basson and Kriek's (2012) study on Physical Science teaching found that, at the core of effective science teaching, is the need for teachers to possess specialised knowledge and skills, which, Olitsky (2006) argues, should start at school level.

\section{Thobani's challenge of dealing with his HOD and older colleagues}

Mellville, Hardy and Bartley (2011:2276) assert that formidable challenges await teachers who are looking to contest the hegemony of traditional teaching strategies without sustained support to overcome such challenges. Bourdieu (1977) points 
out that social worlds, such as the science department in Thobani's school, are comprised of different social spaces or 'fields' within which individuals engage in contests. These contests occur between individuals whose dispositions or 'habitus'the way they behave and feel - makes them more likely or able to engage in the roles and responsibilities assigned to them in schools or other related fields. These social spaces are represented subconsciously to orient a person's awareness and actions. For this reason, individuals perceive the same opportunity differently because of their different dispositions. This could explain the responses of Thobani's colleagues, who may have developed or adopted a 'habitus' that defined the relationship between learners, the learning culture and its associated change differently from his. The upshot of this situation is usually 'a space of conflict' and competition: the older teachers dominate and the new ones struggle to have their voices heard.

Bantwini (2010) argues that, at the heart of successful curriculum implementation, is continuous professional development. At Thobani's school, professional development was non-existent and, instead of encouraging Thobani, who was fresh from university, his HOD and senior colleagues were opposed to his decision to implement the NCS and put many obstacles in his way. To aggravate matters, the workshops and training offered to him by the Department of Education as a form of professional development he found at best 'confusing' and 'a waste of time'. He pointed out that it was through self-study and sacrifice that he came to understand the curriculum and the new content associated with it. He mainly used the assessment tools provided by the department (such as specimen questions and answers, old question papers and examination guidelines) to plan and deliver the content to his learners. That he paid relatively little attention to LO 1 (Ass 1.1, 1.2, 1.3 and 1.4) and LO 3 (Ass 3.1, 3.2 and 3.4) and had to learn the curriculum on his own suggests that he moulded the curriculum to fit his context and understanding. Waugh and Punch (1987) contend that, although teachers take ownership of curriculum change, the implemented curriculum is not always the enacted curriculum. According to Cuban (1998), this happens because teachers will adapt and modify the anticipated outcomes to suit their purpose. Therefore, the possibility exists that there might be a disjuncture between the teachers' conceptions and beliefs and those of the prescribed or intended curriculum. This raises the question of how Thobani perceived the NCS, based on his recollections as captured in the interview responses.

\section{Heidegger and Thobani's epistemic nature}

Thobani's perceptions or consciousness of the NCS might best be explained using Heidegger's (1967) concepts of 'hammering' and 'the coping being'. According to Heidegger (1967), dasein (being in the situation) always involves a type of mood such as anxiety or a feeling of being threatened as an emotional manifestation of the nature of the being. Heidegger argues that mood is always present in any situation 
and that, when people enter a situation, they move in behind its mood. Heidegger uses the word hammering to explain what happens in the mind of a carpenter as he or she knocks the nails into a piece of wood while building a cupboard. Hammering comprises two processes, namely ready-to-handle and unready-to-handle situations (Heidegger 1967).

In the ready-to-handle situation (present at hand), the carpenter is not in a state of awareness as the process of using a hammer is transparent, self-evident and requires no thought. All that is important at that moment is the act of using the hammer to knock nails into wood or some other object. Heidegger describes the carpenter as being cognitively asleep or unaware of the situation or surroundings. This example of hammering depicts how, not only craftspersons, but also teachers go about their work unreflectively, that is, without questioning the status quo or giving any thought to the process. Like carpenters, teachers only work towards achieving their goal, which is to finish the project they are working on and to move on. The aforementioned reveals that teachers might have a particular understanding of the curriculum that they continue to follow/implement. Whether their understanding is authentic or unauthentic, their actions represent their psychological condition. Heidegger's main thesis is that one's psychological condition or state of mind is grounded primarily in 'what has always been' (Heidegger 1967:341). The latter becomes a mode of projectedness within which a person's mind becomes caged. However, the situation and the mood change into a state of heightened awareness on the part of the craftsperson when the use of the hammer becomes problematic or too difficult for the task at hand. Now the craftsperson is forced make adjustments to the way the tool is being used by either modifying, repairing or replacing it. In this unready-to-handle situation, the coping part of the process represents the heightened state of cognitive awareness that forces the carpenter to observe the situation more closely and reflect on it in an attempt to ameliorate the situation. In the process, the carpenter's regular life world is filled with uncertainty, confusion or disorder as he or she now has to think about what has been happening. Heidegger believes that we only become conscious when things go wrong. Furthermore, he argues that this new state of mind (heightened awareness) has its origin in 'the temporality of concern' (1967:400). Factually, this temporality of concern becomes necessary to approximate new goals, which subsequently requires a new way of 'seeing' or looking at the world (or some concept), giving birth to new ideas or understanding. Similarly, teachers are forced out of their comfort zone when the prevailing policies, procedures or curricula become obsolete, or when they are suddenly challenged or replaced.

In Thobani's case, he instinctively and intuitively responded to the challenge of finding a new phenomenological coping mechanism when the tools of his trade became ineffective due to the introduction of a new curriculum for Physical Science. Forced to adapt, Thobani now had to reflect deeply on how to replace the 
old, unreflective ways of doing things with a fundamentally new approach. This involved constant reflection and revision as he attempted to address the problem areas of the curriculum. In the process, he managed to dismiss negative thoughts and ideas in order to accept the challenge of curriculum change, while at the same time adopting a positive mind-set and attitude. This mind-set allowed him to see the NCS, not as something forced upon him, but as an opportunity for professional and inner growth. Accepting the challenge and cultivating a positive mind-set, despite the many depressing obstacles put in his way, assisted him in acting out his convictions in such a way that he became tolerant, flexible and susceptible to change. In essence, what Thobani shows us is that there is no mystery to change. Essentially, it is about accepting new ideas and making a cognitive leap to address new challenges.

\section{CONCLUSION}

This article presents a phenomenological recount of a Physical Science teacher's lived experiences while implementing the NCS. It provides both a descriptive narrative (using Husserlian phenomenology) and an interpretive narrative (using Heideggerian phenomenology) to report the findings. The article focuses on Thobani's experiences, the act of being per se, and the process of being in the midst of the curriculum delivery process. We discover Thobani's fundamental relation to the curriculum, his peers, and colleagues. The findings indicate that, from the outset, Thobani wanted to become an active implementer of the NCS despite struggling to understand the curriculum. His desire to implement the NCS is revealed by his responses to his peers. His account of being at loggerheads with his peers and his HOD points to his efforts to implement the curriculum. From a Heideggerian perspective, Thobani's existential experiences and the development of his phenomenological attitude might have emerged from various metaphysical and ethical experiences during childhood, namely, his struggle as a learner of Physical Science.

The most striking finding about Thobani's childhood experiences is how an incompetent Grade 12 Physical Science teacher was responsible for his ending up in the teaching profession. Not only did this experience leave him with an inadequate understanding of Physical Science but it made the process of implementing the NCS syllabus very difficult as he struggled to make sense of the content he was required to teach. Another significant finding is that the poor support and encouragement he received from his HOD and the departmental officials made it extremely difficult for him to implement a challenging new syllabus in the absence of the necessary institutional and collegial support. However, despite the undermining influence of the negative responses and repeated ridicule of some of his colleagues, Thobani still managed to hold onto his belief that the NCS curriculum prepares learners for a better future career in science, which motivated him to implement it. The latter is substantiated by the following excerpt: "They were now better prepared for 
university.' Thobani's philosophy is not idealistic because, in his own consciousness, he sees himself as an active implementer of the NCS, despite the challenges of poor support structures at school, the department's lack of good teacher training workshops in both content and curriculum studies, and the absence of continuous professional development.

The data from the phenomenological interview generated a rich description of the formidable challenges teachers face when confronted with a radical curriculum change. The data also provided a clear picture of the life world of a black Physical Science teacher in an informal settlement. The insights gained from this study go beyond the factual theories and rhetoric, and therefore assist curriculum planners and advisors to understand that successful curriculum implementation hinges on teachers. According to Clarke and Linder (2006), without considerable teacher support and development, curriculum initiatives will continue to fail. Therefore, this study provides compelling evidence of the crucial role that teachers play in determining what goes on in the science classroom and the long-term consequences it has for the learner.

This article highlights an important issue for the field of curriculum studies in South Africa, which raises a concern about the latest version of the NCS, the Curriculum and Assessment Policy Statement (CAPS). This document is a highly prescriptive curriculum framework that dictates when, what and for how long topics should be taught and learned. Over the past few decades, curriculum discourses in South Africa have privileged the policy-maker's world (see Le Grange 2007) to such an extent that only one view of curriculum has been legitimated, namely curriculumas-planned. Thobani's narrative, as reported in this article, highlights the importance of another view of curriculum: curriculum-as-lived - a view that recognises the lived or living experiences of teachers. Acknowledging curriculum-as-lived does not mean dismissing curriculum-as-planned, but brings to the fore a tensioned space between the two views of curriculum that teachers (as illustrated in Thobani's narrative) negotiate daily, a space that has not been researched or theorised sufficiently in South Africa. We aver that greater recognition of this tensioned space could be pivotal in efforts to transform education in South Africa. Aoki (1999:181) cogently explicates this tensioned space as follows:

It is in this space of between that our teachers, sensitive to both curriculum-as-planned and curriculum-as-lived, dwell, likely finding it a tensioned space of ambiguity, ambivalence, and uncertainty but simultaneously a vibrant site. It looks like a simple oppositional binary space, but it is not. It is as space of doubling, where we slip into the language of "both this and that, but neither this nor that". Our teachers slip into the language of "both plannable and unplannable, but neither strictly plannable nor strictly unplannable." Confusing? Yes, Confusingly complex? Yes. But nevertheless a site that beckons pedagogic struggle, for such as human site promises generative possibilities and hope. It is, indeed, a site of becoming, where newness can come into being. 


\section{REFERENCES}

Aldous, C. 2004. Science and mathematics teachers' perceptions of C2005 in Mpumalanga secondary schools. African Journal of Research for Mathematics, Science and Technology Education 8(1):65-76.

Aoki, T. 1999. Interview. Rethinking curriculum and pedagogy. Kappa Delta PiRecord. Summer: $180-181$

Bansilal, S. \& Wallace, J. 2008. National performance assessment in a South African context: A case study of issues of classroom implementation and task design. African Journal of Research in Mathematics, Science and Technology Education 12:77-92.

Bantwini, B. 2010. How teachers perceive the new curriculum reform: Lessons from a school district in the Eastern Cape Province, South Africa. International Journal of Educational Development 30:83-90.

Basson, I. \& Kriek, J. 2012. Are grade 12 physical science teachers equipped to teach physics? Perspectives in Education 30(3):110-122.

Bennet, R. 2002. Unconscious consciousness in Husserl and Freud. Phenomenology and the Cognitive Sciences 1:327-351.

Bourdieu, P. 1977. Outline of a theory of practice. Cambridge: Cambridge University Press.

Brodie, K., Lelliot, A. \& Davis, H. 2002. Forms and substance in learner-centred teaching: Teachers' take up from an in-service program in South Africa. Teacher and Teacher Education 18(5):541-559.

Brown, R.K. 1992. Max van Manen and pedagogical human science research. In W.F. Pinar \& W.M. Reynalds (Eds.), Understanding curriculum as phenomenological and deconstructed text, 44-63. New York: Teachers College Press.

Chisholm, L., Volmink, J., Ndhlovu, T. et al. 2000. A South African curriculum for the twenty first century: Report of the review committee on Curriculum 2005. Pretoria: Department of National Education.

Clarke, J. \& Linder, C. 2006. Changing teaching, changing times: Lessons from a South African township science classroom. Sense Publishers, Rotterdam/Taipei.

Cuban, L. 1998. How schools change reforms: Redefining reform success and failure. Teachers College Record 99 (3):453-477.

Department of Basic Education (DBE). 2002. Revised National Curriculum Statement: Grades R-9 (Schools): Policy, Natural Sciences. Pretoria: DBE.

Department of Basic Education. 2006. Physical Sciences National Curriculum Statement: Grades 10-12 (General). Pretoria: DBE.

Department of Education. 1997. Curriculum 2005. Retrieved from http://www.polity.org.za/ govdocs/misc/curr2005html (accessed 13 November 2013).

Department of Education. 2003. National Curriculum Statement for Further Education and Training. Discussion document. Pretoria: DBE.

Department of Basic Education. 2006. National Curriculum Statement for Further Education and Training. Discussion document. Pretoria: DBE.

Department of Basic Education. 2008. National Curriculum Statement for Further Education and Training. Discussion document. Pretoria: DBE. 
Domert, D., Airy, J., Linder, C. \& Kung, R.L. 2007. An exploration of university physics students' epistemological mindsets towards the understanding of physics equations. Nordidina 1:1529.

Gardamer, H.G. 1975. Truth and method. New York: Seabury.

Hammer, D. 1995. Epistemological considerations in teaching introductory physics. American Journal of Physics, Physics Education Research Supplement 68:52-59.

Haney, J.J., Czerniak, C.M. \& Lumpe, A.T. 1996. Teacher beliefs and intentions regarding the implementation of science education reform standards. Journal of Research in Science Teaching 33:971-993.

Hattingh, A., Rogan, J.M., Aldous, C., Howie, S. \&Venter, E. 2005. Assessing the attainment of learner outcomes in Natural Science of the new South African curriculum. African Journal of Research for Mathematics, Science and Technology Education 9(1):13-24.

Heidegger, M. 1967. Being and time (Translated from the German by Macquarrie, J. \& Robinson, E.). London: SCM Press.

Heidegger, M. 2002. The essence of truth (Translated from the German by Sadler, T.). New York, NY: Continuum.

Husserl, E. 1970. The crisis of the European sciences and transcendental phenomenology: An introduction to phenomenological philosophy. Translated from the German by Carr, D. Evanston, IL: North-Western University Press.

Husserl, E. 1975. The Paris lectures (P. Koesterbaum, Trans.). The Hague: Martinus Nijhoff.

Hycner, R. 1985. Some guidelines for the phenomenological analysis of interview data. Human Studies 8:279-303.

Jansen, J. 1999. A very noisy OBE: The implementation of OBE in Grade 1 classrooms. In J.

Jansen \& P. Christie (Eds.), Changing curriculum: Studies on outcomes based education in South Africa, 1-15. Cape Town: Juta.

Jansen, J.D. \& Christie, P. (Eds.). 1999. Changing curriculum: Studies on outcomes-based education in South Africa. Cape Town: Juta.

Koopman, O. 2013. Teachers' experiences of Implementing the Further Education and Training Science Curriculum. Unpublished doctoral thesis, Stellenbosch University, Stellenbosch, South Africa.

Kriek, J. \& Basson, I. 2008. Implementation of the new FET Physical Science curriculum: Teachers' perspectives. African Journal of Science, Mathematics and Technology Education, Special edition: 63-76.

Le Grange, L. 2007. (Re)thinking outcomes-based education: From arborescent to rhizomatic conceptions of outcomes (based-education). Perspectives in Education 25(4):79-85.

Le Grange, L. \& Reddy, C. 2000. Introducing teachers to OBE and EE: A Western Cape case study. South African Journal of Education 20(1):28-32.

McDonald, M.A. \& Rogan, J.M. 1988. Innovation in South African science education: Science teaching observed. Science Education 72(2):225-236.

Mellville, W., Hardy, I. \& Bartley, A. 2011. Bourdieu, department chairs and the reform of science education. International Journal of Science Education 33(16):2275-2293. 
Miles, M.B. \& Huberman, A.M. 1984. Qualitative data analysis: A sourcebook of new methods. Newbury Park, CA: Sage.

Nakedi, M., Taylor, D., Mundalamo, F., Rollnick, M. \& Mokeletche, M. 2012. The story of a physical science curriculum: Transformation or transmutation. African Journal of Mathematics Science and Technology Education 6(3):273-288.

Ogunniyi, M.B. 1996. Science, technology and mathematics: The problem of developing critical human capital in Africa. International Journal of Science Education 18(3):267-284.

Olitsky, S. 2006. Facilitating identity formation, group membership, and learning in science classrooms. Science Education 10:201-223.

Rogan, J.M. 2004. Out of the frying pan ...? Case studies of the implementation of Curriculum 2005 in some science classrooms. African Journal of Science, Mathematics and Technology Education 8(2):165-179.

Rogan, M.R. \& Grayson, D.J. 2003. Towards a theory of curriculum implementation with particular reference to science education in developing countries. International Journal of Science Education 25(10):1171-1204.

Van Manen, M. 1984. Practising phenomenological writing. Phenomenology and Pedagogy 2(1):36-69.

Waugh, R.F. \& Punch, K.F. 1987. Teacher receptivity to system-wide change in the implementation phase. Review of Educational Research 57(3):237. 